\title{
KAJIAN GLISEMIK INDEKS DAN MAKRONUTRIEN DARI UMBI-UMBIAN DALAM UPAYA PENCARIAN SUMBER PANGAN FUNGSIONAL
}

\section{STUDY OF GLICEMIKC INDEX AND MACRONUTRIENT CONTENT FROM TUBERS TO FIND ALTERNATIVE FUNCTIONAL FOOD}

\author{
Endang Lukitaningsih*, Rumiyati, lka Puspitasari \\ Fakultas Farmasi, Universitas Gadjah Mada Yogyakarta \\ lukitaningsih_end@ugm.ac.id
}

\begin{abstract}
ABSTRAK
Dewasa ini, di Indonesia eksplorasi untuk mencari bahan pangan alternatif pengganti beras masih terus dilakukan. Kandungan makronutrien dan kajian glisemik indeks dari umbi ganyong (Canna edulis Kerr.), walur (Amorphophallus variabilis), porang (Amorphophallus Oncophyllus Prain), suweg (Amorphophallus campanulatus BI) dan uwi (Dioscorea alata L.) telah dilakukan pada penelitian ini dan bertujuan untuk memberikan dasar ilmiah pemilihan pangan alternatif, terutama bagi penderita diabetes mellitus dan obesitas. Pengukuran kandungan makronutrien meliputi kandungan karbohidrat mereduksi dan tidak mereduksi, protein dan serat dilakukan mengacu pada metode AOAC (1990), sedangkan glisemik indeks ditetapkan secara in vivo menggunakan hewan percobaan tikus jantan galur Wistar. Glisemik indeks sampel umbi-umbian seluruhnya lebih rendah dari glisemik indeks beras $(72,8)$. Harga glisemik indeks sangat dipengaruhi oleh kandungan serat, sedangkan pengaruh kandungan karbohidrat terhadap harga glisemik indeks tidak dapat diamati. Walur dan porang memiliki kandungan serat yang besar, yaitu masing-masing 15,09\% dan 11,27\%, sedangkan harga glisemik indeks masing-masing sekitar 20,6 dan 16,9.
\end{abstract}

Kata kunci: glisemik indeks, makronutrien, karbohidrat, serat, protein

\section{ABSTRACT}

Currently, in Indonesia the exploration to find alternative food for replacing rice is still developing. Assessment and measurement of macronutrient content and glycemic index of ganyong (Canna edulis Kerr.), walur (Amorphophallus variabilis), porang (Amorphophallus Oncophyllus Prain), suweg (Amorphophallus campanulatus BI) and uwi (Dioscorea alata L.) have been carried out to provide a scientific basis selection of alternative food sources, especially alternative foods for people having diabetes mellitus and obesity problems. The measurements of macronutrient content (reduce and not reduce of carbohydrate, protein and fiber) have been conducted according to procedures in AOAC (1990), while the glycemic index determined by in vivo experiments using male rats (Wistar species). Glycemic indexes of samples are lower than glycemic index of rice (72.8). In this case, glycemic index value is strongly influenced by the fiber content, while the effect of carbohydrates on glycemic index value cannot be clearly observed. Walur and porang have high fiber content, respectively $15.09 \%$ and $11.27 \%$, while their value of glycemic index are approximately 20.6 and 16.9.

Key words: glycemic index, makronutrient, carbohydrate, fiber, protein

\section{PENDAHULUAN}

Ketergantungan masyarakat Indonesia terhadap beras makin hari makin mengkhawatirkan dengan makin menyempitnya lahan penanaman padi di hampir semua wilayah Indonesia. Untuk mengatasi hal ini, upaya penggalian sumber bahan makanan pokok lokal seperti pemanfaatan umbi-umbian patut dilakukan. Pembuktian ilmiah berdasarkan kajian kandungan nutrisi dan indeks glisemik perlu dilakukan untuk menyiapkan bahan pangan yang dapat dikonsumsi bagi penderita diabetes mellitus atau obesitas. Seperti diketahui bahwa penderita kedua kasus tersebut hingga kini terus meningkat.

Glisemik indek (GI) merupakan gambaran tentang hubungan karbohidrat dalam makanan dengan kadar glukosa darah. Pangan yang dapat menaikkan gula darah dengan cepat biasanya memiliki glisemik indek tinggi (Rimbawan \& Siagian, 2004). Gl digunakan juga untuk standarisasi respon glisemik terhadap adanya karbohidrat (sebagai contoh: gula dan pati) dan makanan yang kaya akan karbohidrat, seperti beras, 
buah- buahan, sayuran, dan produk coklat (Jenkins dkk, 1984). Saat ini penggunaan Gl tidak hanya terbatas pada penderita diabetes, akan tetapi juga digunakan dalam pemilihan pola makan yang sehat, proses pengurangan berat badan, dan dalam proses lain untuk mengubah penampilan fisik seseorang (Campbell, 2010).

Tiap makanan memiliki nilai glisemik indek yang berbeda-beda dan dapat digolongkan menjadi 3 kelas, yaitu indek glikemik tinggi (>70), glisemik indek moderat (70-56), dan indek glikemik rendah $(<55)$. Beberapa makanan yang memilki nilai glisemik indek tinggi antara lain adalah roti, sereal, permen, dan kentang (Foster-Powel dkk., 2002).

Kandungan dasar glisemik indek dalam makanan, sifat fisik dari amilum, kandungan gula, keasaman, dan kandungan serat merupakan faktor- faktor yang berpengaruh terhadap konversi karbohidrat menjadi glukosa (Kalergis dkk, 2005). Dengan dilakukannya diet makanan rendah glisemik indeks, maka akan memberikan efek positif bagi kesehatan seperti menurunnya kebutuhan insulin (Augustin et al., 2002)

Untuk dapat menggantikan beras sebagai bahan makanan pokok, maka perlu dilakukan pengujian komponen makronutrien. Makronutrien merupakan nutrisi-nutrisi utama yang terdapat di dalam produk Makanan

dalam jumlah yang relatif besar, seperti kandungan karbohidrat mereduksi dan non mereduksi, protein dan serat. Selain sebagai molekul tunggal, monosakarida juga berfungsi sebagai bahan dasar dalam sintesis karbohidrat kompleks seperti pati/amilum (Robinson, 1991). Amilum merupakan bentuk polimer karbohidrat yang banyak tersimpan pada bagian umbi dan rimpang dari tanaman. Amilum bersifat tidak larut di dalam air dingin, tetapi larut di dalam air panas membentuk cairan yang sangat pekat seperti pasta, peristiwa ini disebut gelatinisasi. Dalam saluran pencernaan, gel dari amilum ini diduga dapat melapisi permukaan mukosa dari lambung. Selain mampu memperlambat terjadinya proses difusi asam lambung, keberadaan gel juga meningkatkan pertahanan mukosa dengan cara mengikat senyawa pepsin (Isselbacher dkk., 2000).

\section{METODOLOG \\ Alat}

Neraca analitik sentrifugator (EBA Germany), alat-alat pompa vakum, (Spektrofotometer
(Boeco, Germany), 20 Hettich Zentrifugen, gelas, corong Buchner, buret, Spektrofotometer Genesys UV10-Thermo
Electrone Corporation), penyerbuk (Tiger, Indonesia).

\section{Bahan}

Umbi uwi, ganyong, suweg, walur dan porang, beras, $\mathrm{HCl}, \mathrm{NaOH}, \mathrm{NaCl}$, aceton, petroleum eter, kloroform, $\mathrm{H}_{2} \mathrm{SO}_{4}$, Na-tungstat anhidrat, $\mathrm{K}_{3} \mathrm{Fe}(\mathrm{CN})_{6}, \mathrm{Na}_{2} \mathrm{CO}_{3}, \mathrm{KCl}, \mathrm{ZnSO} 4.7 \mathrm{H}_{2} \mathrm{O}$, kanji, $\mathrm{KI}, \mathrm{Na}_{2} \mathrm{~S}_{2} \mathrm{O}_{3}, \mathrm{Na}_{2} \mathrm{~B}_{4} \mathrm{O}_{7} .10 \mathrm{H}_{2} \mathrm{O}, \mathrm{CMC} \mathrm{Na}$ (Merck, Germany), GOD PAP assay kit (DiaSys, Germany) yang berisi buffer fosfat $\mathrm{pH} 7,5$ (250 $\mathrm{mmol} / \mathrm{L})$, fenol $(5 \mathrm{mmol} / \mathrm{L})$, 4aminoantipyrine $\quad(0,5 \mathrm{mmol} / \mathrm{L}), \quad$ glukosa oksidase (GOD) ( $\geq 10 \mathrm{kU} / \mathrm{L})$, peroksidase (POD) ( $\geq 1 \mathrm{kU} / \mathrm{L})$, standar glukosa $100 \mathrm{mg} / \mathrm{dL}$.

\section{Hewan Uji}

Tikus putih (Rattus norvegicus) galur Wistar jantan dengan usia rata-rata 2 sampai 3 bulan, berat badan 150-200 gram yang diperoleh dari Unit Pengembangan Hewan Percobaan (UPHP) UGM.

\section{Jalannya Penelitian \\ Preparasi sampel}

Umbi suweg, walur, porang, ganyong dan uwi diambil dari dusun Pule, Sugihan, Bulukerto, Wonogiri, Jawa Tengah pada bulan Juli-Agustus 2011. Umbi dikupas dan dicuci bersih, kemudian diiris tipis-tipis.

Umbi suweg, walur dan porang perlu dihilangkan getah gatalnya sebelum dilakukan analisis lebih lanjut. Penghilangan getah gatal dilakukan secara asam basa, menggunakan $\mathrm{HCl}$ 0,01 dengan lama perendaman 15 menit dan selanjutnya dicuci menggunakan $\mathrm{NaOH}$ 0,01 hingga netral, kemudian dibilas dengan air.

Irisan sampel kemudian dikeringkan dalam oven $60^{\circ} \mathrm{C}$ hingga kering, selanjutnya diserbuk dan ditetapkan kandungan airnya secara gravimetri.

\section{Penetapan Kadar Air}

Cawan alumunium yang telah dikeringkan dan diketahui bobotnya diisi sebanyak $2 \mathrm{~g}$ sampel lalu ditimbang (W1) kemudian dimasukkan ke dalam oven suhu $105{ }^{\circ} \mathrm{C}$ selama 1-2 jam. Cawan alumunium dan sampel yang telah dikeringkan dimasukkan ke dalam desikator kemudian ditimbang setelah dingin.

\section{Analisis Kandungan Karbohidrat}

Kandungan karbohidrat yang diperiksa meliputi kandungan gula mereduksi dan tidak mereduksi mengacu pada metode AOAC 1990.

Persiapan: ditimbang 5,675 gram tepung sampel dan ditempatkan dalam tabung erlenmeyer. Kemudian ditambahkan $5 \mathrm{ml}$ etanol dan 50,0 $\mathrm{ml}$ larutan bufer asetat. Larutan 
digojok hingga tepung tersuspensi dalam cairan. Selanjutnya segera ditambahkan $2 \mathrm{ml}$ Na-tungstat dan penggojokan dilanjutkan. Larutan disaring menggunakan kertas whatman.

Analisis kandungan karbohidrat mereduksi: diambil 5,0 ml larutan di atas dan ditempatkan dalam tabung kaca. Ditambahkan ke dalamnya sebanyak $10 \mathrm{ml}$ larutan $\mathrm{K}_{3} \mathrm{Fe}(\mathrm{CN})_{6}$, larutan digojok dan dipanaskan dalam penangas air selama 20 menit. Larutan kemudian didinginkan dan dipindahkan ke dalam erlenmeyer. Tabung dibilas dengan $25 \mathrm{ml}$ larutan garam asetat. Selanjutnya larutan ditambah $1 \mathrm{ml}$ indikator kanji-idodida. Larutan dititrasi dengan larutan $0,1 \mathrm{~N} \mathrm{Na}_{2} \mathrm{~S}_{2} \mathrm{O}_{3}$ hingga terbentuk warna biru. Dikerjakan titrasi blangko untuk mengkoreksi kesetaraan antara $\mathrm{K}_{3} \mathrm{Fe}(\mathrm{CN})_{6}$ dan $\mathrm{Na}_{2} \mathrm{~S}_{2} \mathrm{O}_{3}$. Selanjutnya volume $\mathrm{K}_{3} \mathrm{Fe}(\mathrm{CN})_{6}$ dihitung dan dimasukkan ke dalam tabel konversi untuk mengetahui kandungan sukrosa per 10 gram tepung (AOAC)

Analisis kandungan karbohidrat tidak mereduksi: Dipipet 5,0 ml larutan di atas dan dimasukkan ke dalam tabung, selanjutnya dipanaskan dalam penangas air selama 15 menit. Tabung didinginkan dan dipindahkan ke dalam erlenmeyer. Tabung dibilas dengan larutan garam asetat. Larutan kemudian ditambah $10,0 \mathrm{ml}$ larutan $\mathrm{K}_{3} \mathrm{Fe}(\mathrm{CN})_{6}$ dan digojok. Ditambahkan indikator $1 \mathrm{ml}$ kanji-iodida dan dititrasi menggunakan larutan $0,1 \mathrm{~N}$ $\mathrm{Na}_{2} \mathrm{~S}_{2} \mathrm{O}_{3}$ hingga terbentuk warna biru. Kadar karbohidrat tidak mereduksi $=$ volume $\mathrm{K}_{3} \mathrm{Fe}(\mathrm{CN})_{6}$ yang direduksi setelah hidrolisis volume $\mathrm{K}_{3} \mathrm{Fe}(\mathrm{CN})_{6}$ yang direduksi oleh gula mereduksi.

\section{Uji Kandungan Protein \\ Pembuatan kurva baku:}

Ditimbang bovine serum albumin (BSA) sebanyak 1,25 g dan dimasukkan ke dalam labu takar $25 \mathrm{ml}$. Ditambahkan aquades sedikit untuk membasahi albumin, kemudian ditambahkan aquades hingga 25,0 ml. Dibuat kurva baku albumin dengan seri kadar 100-700 $\mu \mathrm{g} / \mathrm{mL}$ dengan komposisi seperti Tabel 1.

Tabel 1- Kurva Baku Albumin

\begin{tabular}{cccccc}
\hline No & $\begin{array}{c}\text { Larutan albumin stok } \\
(\boldsymbol{\mu L})\end{array}$ & $\begin{array}{c}\text { Kadar BSA } \\
(\mathbf{m g} / \mathbf{m L})\end{array}$ & $\begin{array}{c}\text { Bufer fosfat } \\
\mathbf{0 , 1} \mathbf{M} \mathbf{~ p H ~ 7 , 5} \\
(\boldsymbol{\mu L})\end{array}$ & $\begin{array}{c}\text { Reagen Biuret } \\
\mathbf{0 , 1} \mathbf{~ M}(\boldsymbol{\mu L})\end{array}$ & Keterangan \\
\hline 1 & 20 & 1,0 & 180 & 800 & - \\
2 & 30 & 1,5 & 170 & 800 & - \\
3 & 40 & 2,0 & 160 & 800 & - \\
4 & 60 & 3,0 & 140 & 800 & - \\
5 & 80 & 4,0 & 120 & 800 & Blangko \\
6 & - & - & 200 & 800 & Sampel \\
7 & 100 (Sampel) & & 100 & 800 & \\
\hline
\end{tabular}

Setelah didiamkan selama 10 menit, larutan diukur absorbansinya pada panjang gelombang $550 \mathrm{~nm}$. Kemudian dibuat kurva hubungan antara konsentrasi BSA (sebagai sumbu $\mathrm{X}$ ) dengan absorbansi (sebagai sumbu $Y$ )

Sebanyak 1,0 gram serbuk suweg, walur dan porang dilarutkan dalam $7 \mathrm{~mL}$ bufer fosfat $\mathrm{pH}$ 7,5 kemudian disaring dan supernatan diambil dan ditambah bufer fosfat hingga volume tepat $10,0 \quad \mathrm{~mL}$. Selanjutnya filtrat dibaca absorbansinya pada panjang gelombang 550 $\mathrm{nm}$. Absorbansi filtrat dimasukkan ke dalam persamaan kurva baku tersebut dan dihitung konsentrasi proteinnya.

\section{Analisis Kandungan Serat}

Kandungan serat ditetapkan dengan metode gravimetri. Ditimbang tepung sampel sebanyak 10 gram. Tepung disoxhletasi menggunakan petroleum eter selama 6 jam. Tepung yang telah bebas lemak kemudian ditambah $200 \mathrm{~mL} \mathrm{H} \mathrm{HO}_{4}$ 0,255 $\mathrm{N}$ dan direfluks selama satu jam. Campuran disaring dan endapan dinetralkan dengan air panas. Endapan netral ditambah $200 \mathrm{~mL}$ larutan $0,255 \mathrm{~N} \mathrm{NaOH}$ dan direfluks selama
1 jam. Kemudian disaring melalui kertas saring yang telah diketahui beratnya sambil dicuci dengan larutan $\mathrm{K}_{2} \mathrm{SO}_{4} \quad 10 \%$. Residu dicuci lagi dengan aquadest mendidih dan kemudian dengan lebih kurang $15 \mathrm{~mL}$ alkohol $95 \%$. Kertas saring dengan isinya dikeringkan pada $110^{\circ} \mathrm{C}$ sampai berat konstan, kemudian didinginkan dalam eksikator dan ditimbang.

\section{Penetapan Glisemik Indek}

Penentuan nilai glisemik indeks dilakukan dengan hewan coba tikus usia dewasa (20 minggu) yang diberi sampel seberat $2 \mathrm{~g} / \mathrm{kg}$ berat badan (BB), dibandingkan dengan glukosa dengan berat yang sama. Pemberian bahan uji dilakukan secara oral, kemudian dilakukan sampling darah tikus sesaat sebelum pemberian bahan uji, 10, 30, 60 dan 120 menit. Dilakukan penetapan kadar glukosa darah pada waktu sampling tersebut dengan metode GOD-PAP. Pengukuran kadar glukosa dilakukan pada serum darah tikus. Percobaan dilakukan sebanyak tiga kali replikasi. 


\section{HASIL DAN PEMBAHASAN}

Sebelum dilakukan analisis lebih lanjut, kadar air serbuk sampel perlu diketahui ditetapkan untuk keperluan perhitungan dan kontrol kualitas. Hasil penetapan kadar air serbuk menunjukkan beras memiliki kadar air tertinggi (Tabel 2).

Tabel 2- Kadar air dalam tepung ganyong, suweg, walur dan porang serta beras

\begin{tabular}{lll}
\hline \multirow{2}{*}{ Nama } & \multicolumn{2}{l}{ Kadar Air (\%) } \\
\cline { 2 - 3 } & Rerata & SD \\
\hline Ganyong & 7,45 & 0,35 \\
Suweg & 8,40 & 0,42 \\
Walur & 8,95 & 0,21 \\
Porang & 9,55 & 0,07 \\
Beras & 11,10 & 0,71 \\
\hline
\end{tabular}

Seperti diketahui, bahwa suweg, walur dan porang merupakan umbi yang menimbulkan rasa gatal bila kontak dengan kulit. Rasa gatal

A

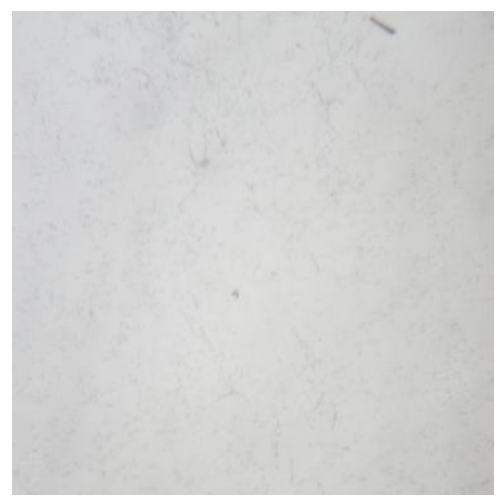

C

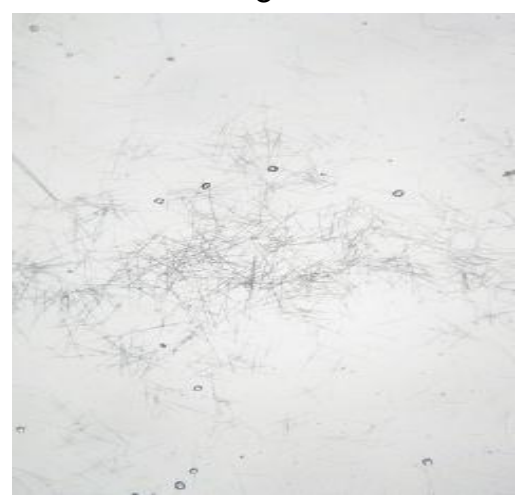

disebabkan karena kandungan calcium oksalat di dalamnya. Hasil pemeriksaan mikroskopik dari getah ketiga umbi menunjukkan umbi walur memiliki kandungan kalsium oksalat paling banyak dan memang sangat gatal dibanding umbi yang lain (Gambar 1). Agar dapat dikonsumsi, maka getah gatal tersebut harus dihilangkan terlebih dahulu. Dari data penelitian yang lain, diperoleh informasi bahwa penghilangan getah gatal dapat dilakukan dengan jalan mencuci irisan umbi menggunakan $\mathrm{HCl} \quad 0,01 \mathrm{~N}$ dan direndam selama 15 menit, kemudian dicuci dengan $\mathrm{NaOH} 0,01 \mathrm{~N}$ hingga $\mathrm{pH}$ normal. Selanjutnya dicuci dengan air hingga bersih.

Analisis kandungan makronutrien dari keempat sampel menunjukkan kandungan tertinggi karbohidrat merduksi terdapat dalam beras $(15 \%)$ dan kandungan karbohidrat tidak mereduksi terendah $(0,17 \%)$ (Tabel 2$)$.

B

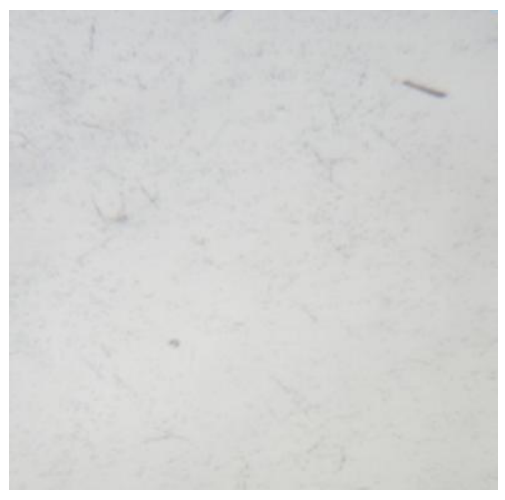

D

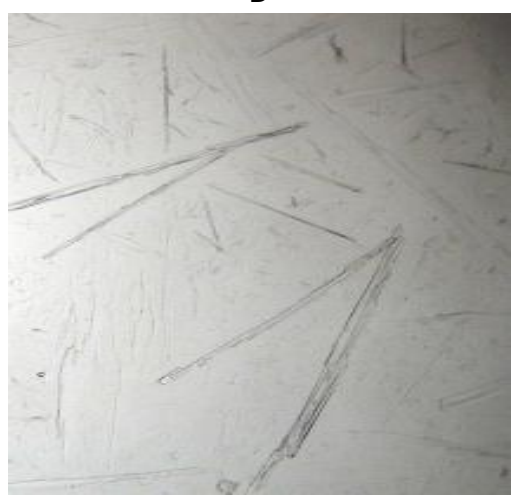

Gambar 1- Gambar mikroskopik kalsium oksalat dari getah umbi porang (A), suweg (B), walur (C) dan standar kalsium oksalat

Tabel 3- Kandungan Karbohidrat mereduksi dan tidak mereduksi dalam sampel

\begin{tabular}{|c|c|c|}
\hline Sampel & $\begin{array}{l}\text { Kandungan karbohidrat mereduksi } \\
(\%)\end{array}$ & $\begin{array}{l}\text { Kandungan karbohidrat tidak } \\
\text { mereduksi (\%) }\end{array}$ \\
\hline Ganyong & $3,44 \pm 0,50$ & $2,85 \pm 0,27$ \\
\hline Suweg & $1,64 \pm 0,11$ & $1,50 \pm 0,03$ \\
\hline Walur & $1,59 \pm 0,04$ & $1,48 \pm 0,06$ \\
\hline Porang & $3,12 \pm 0,14$ & $2,56 \pm 0,20$ \\
\hline Uwi & $4,01 \pm 0,15$ & $2,96 \pm 0,14$ \\
\hline Beras & $15 \pm 0,02$ & $0,17 \pm 0,03$ \\
\hline
\end{tabular}


Perhitungan kandungan karbohidrat dilakukan dengan metode titrimetri berdasarkan AOAC (1990). Hasil penetapan kandungan karbohidrat dapat dilihat pada Tabel 2.

Kandungan karbohidrat terutama kandungan karbohidrat mereduksi dalam sampel sangat erat kaitannya dengan nilai glisemik indeks. Berdasarkan data di atas, walur merupakan sampel dengan kandungan karbohidrat terendah dan sangat prospek digunakan sebagai bahan pangan fungsional bagi penderita diabetes mellitus, diikuti dengan suweg dan porang. Umbi uwi memiliki kandungan karbohidrat terbesar dari keseluruhan sampel, namun demikian kandungannya jauh lebih rendah dibandingkan kandungan karbohidrat beras.

Analisis kandungan protein dalam sampel dikerjakan menggunakan metode biuret dengan prinsip kerja bahwa dua atau lebih ikatan peptida dapat berikatan secara kovalen koordinasi dengan ion $\mathrm{Cu}^{2+}$ dari tembaga(II)sulfat yang terdapat dalam pereaksi biuret dalam suasana alkalis. Hasil penetapan kandungan protein menunjukkan umbi suweg memiliki kandungan protein yang paling tinggi yaitu sekitar 12,35 \% diikuti oleh umbi walur (Tabel 3). Kandungan protein ini merupakan nilai tambah kualitas umbi bila dikonsumsi.

Tabel 4- Kandungan protein dalam sampel

\begin{tabular}{lc}
\hline Sampel & Kadar Protein (\%) \\
\hline Ganyong & $3,91 \pm 0,12$ \\
Suweg & $12,35 \pm 0,26$ \\
Porang & $4,32 \pm 0,23$ \\
Walur & $8,72 \pm 0,47$ \\
Uwi & $0,32 \pm 0,01$ \\
Beras & $0,76 \pm 0,12$ \\
\hline
\end{tabular}

Analisis serat kasar dilakukan berdasarkan metode AOAC (1990). Berbagai penelitian yang telah dilakukan menyatakan bahwa serat makanan dapat berfungsi sebagai proteksi terhadap penyakit tertentu, antara lain penyakit diabetes, obesitas dan kanker kolon (Hidalgo et al., 1997). Hal ini yang mendasari pentingnya dilakukan analisis kandungan serat dalam suatu bahan makanan.

Tabel 5- Kandungan serat kasar dalam sampel

\begin{tabular}{lc}
\hline Sampel & $\begin{array}{l}\text { Kandungan serat kasar } \\
(\%)\end{array}$ \\
\hline Ganyong & $3,84 \pm 0,34$ \\
Suweg & $9,29 \pm 0,42$ \\
Porang & $15,09 \pm 2,25$ \\
Walur & $11,27 \pm 0,43$ \\
Uwi & $6,9 \pm 0,02$ \\
Beras & $1,32 \pm 0,02$ \\
\hline
\end{tabular}

Hasil uji menunjukkan umbi porang dan walur memiliki kandungan serat kasar yang paling tinggi (Tabel 5). Oleh karenanya sangat potensial dikembangkan sebagai pangan fungsional terutama bagi penderita obesitas dan orang dengan keluhan sembelit. Seperti diketahui bahwa keberadaan serat dalam bahan makanan akan meningkatkan reabsorpsi air di dalam usus besar, sehingga tinja tetap melunak.

Glisemik indeks dapat diketahui nilainya melalui perbandingan karbohidrat tertentu dengan karbohidrat referensi (glukosa) (Kalergis et al., 2005). Pada penelitian ini, penetapan nilai glisemik indeks dilakukan dengan menggunakan metode kolorimetri. Glukosa darah hewan percobaan direaksikan dengan enzim glukosa oksidase (GOD) dan potasium ferrisianida, sehingga membentuk potasium ferrosianida yang intensitasnya dapat diukur pada panjang gelombang $546 \mathrm{~nm}$. Jumlah potasium ferrosianida yang terbentuk setara dengan jumlah glukosa yang terkandung di dalam sampel.

Tabel 6- Hasil pengukuran glisemik indeks sampel

\begin{tabular}{lcr}
\hline \multirow{2}{*}{ BAHAN } & \multicolumn{2}{c}{ KADAR GLUKOSA DALAM DAR } \\
\cline { 2 - 3 } & 0 & 1 \\
Glukosa & 72,6 & \\
Walur & 18,3 & \\
Porang & 25,2 & \\
Suweg & 42,4 & \\
Uwi & 10 & \\
Ganyong & 24,2 & \\
Beras & 51,9 & \\
\hline \multicolumn{1}{c}{ Hasil } & menunjukkan semua sampel
\end{tabular}

memiliki harga glisemik indeks lebih kecil daripada glisemik indeks beras (Tabel 6). Walur memiliki harga glisemik indeks paling kecil, kemudian diikuti porang dan ganyong. Harga glisemik indeks dari sampel nampaknya banyak ditentukan oleh kandungan serat, sedangkan pengaruh kandungan karbohidrat mereduksi terhadap harga glisemik indeks tidak begitu jelas teramati. Hal ini dikarenakan kandungan

\begin{tabular}{|c|c|c|c|}
\hline \multicolumn{2}{|c|}{ ARAH PADA JAM KE-(mg/dL) } & \multirow[b]{2}{*}{ AUC } & \multirow[b]{2}{*}{ GI } \\
\hline 1 & 2 & & \\
\hline 108,3 & 126,3 & 207,75 & 100 \\
\hline 23,3 & 5,5 & 35,20 & 16,9 \\
\hline 22,4 & 15,4 & 42,70 & 20,6 \\
\hline 71,1 & 101,2 & 142,90 & 68,8 \\
\hline 26,3 & 33,1 & 47,90 & 23,1 \\
\hline 22,7 & 15,8 & 43,20 & 20,8 \\
\hline 69,8 & 111,1 & 151,30 & 72,8 \\
\hline
\end{tabular}
sampel tidak begitu mencolok perbedaannya. Semakin besar kandungan serat dalam sampel, maka harga glisemik indeks semakin kecil. Adanya serat dimungkinkan akan menghambat absorpsi nutrisi termasuk karbohidrat, sehingga kadar glukosa darah tidak mengalami kenaikan yang besar pasca mengkonsumsi sampel umbiumbian ini. 


\section{KESIMPULAN}

Umbi walur, porang dan suweg mengandung getah yang menimbulkan rasa gatal bila kontak dengan kulit karena mengandung calsium oksalat, sehingga perlu dihilangkan terlebih dahulu melalui proses pencucian secara asam-basa.

Semua sampel mengandung protein, sehingga merupakan nilai tambah bagi pemanfaatan umbi sebagai sumber karbohidrat alternatif pengganti beras.

Harga glisemik indeks semua sampel lebih kecil dibanding harga glisemik indeks beras. Walur memiliki harga glisemik indeks paling kecil $(16,9)$, kemudian diikuti porang dan ganyong, sehingga potensial untuk dikembangkan sebagai pangan fungsional terutama bagi penderita diabetes mellitus dan obesitas.

Harga glisemik indeks sangat dipengaruhi oleh kandungan serat yang ada dalam sampel. Semakin besar kandungan serat, maka semakin kecil harga glisemik indeksnya.

\section{UCAPAN TERIMA KASIH}

Terima kasih disampaikan kepada Fakultas Farmasi, Universitas Gadjah Mada, Jogjakarta atas pemberian Hibah Penelitian Utama, Tahun Anggaran 2011

\section{DAFTAR PUSTAKA}

AOAC. 1990. Official Methods of Analysis.15th Ed. Association of Official Analytical Chemists, Inc., Virginia, USA

Augustin, L.S., Franceschi, S., Jemkin, D.J.A., Kendall, C.W.C and Vecchia, C.L., 2002, Glycemik index in chronic disease: a review, European J., Clin., Natur., 56:1049-1071

Hidalgo, P.M., Hernandez, G.E. and Villanova, G.B., 1997, Determination of insoluble Dietary Fiber Compounds: Cellulose, Hemicellulose and Lignin in Legumes, J. Ars. Pharm., 38(4):357-364

Campbell, B, 2010, Glycemic Load Vs Glycemic Index, Paper of National Strength \& Conditioning Association 1-5.

Foster-Powel, K., Holt, S.H.A. \& Brand-Miller, J.C., 2002, International Tables of Glycemic Index and Glycemic Load Value, Am J Clin Nutr 76:5-56

Isselbacher, K.J., Braunwald, E., Wilson., J.D., Martin, J.B., Fauci, A.S., \& Lasper, D.L., 2000, Harrison Prinsip-Prinsip Dasar IImu Penyakit Dalam, $13^{\text {th }} \mathrm{Ed}$, diterjemahkan oleh Ahmad H. Asdie, 1532-1553, Penerbit Buku Kedokteran, Jakarta.

Jenkis, D.J.A., Wolever, T.M.S. \& Jenkins, A.L., 1984, The Glycemic Response to Carbohidrat Foods, Lancet 2:388-391.

Kalergis, M., Grandpre, E.D. \& Anderson, C., 2005, The Role of the Glycemic Index in the Prevention and Management of Diabetes: A Review and Discussion, Canadian Journal of Diabetes 29(1):27-38.

Rimbawan \& Siagian, A., 2004, Indeks Glikemik Pangan, Cara Mudah Memilih Pangan yang Menyehatkan, Penebar Swadaya, Jakarta.

Robinson, T., 1991, Kandungan Organik Tumbuhan Tinggi, diterjemahkan oleh Kosasih Padmawinata, 14-30, Penerbit ITB, Bandung. 